\title{
Network Orchestration for Value Platform Development
}

\author{
Helen Perks (Corresponding Author) ${ }^{1}$, Christian Kowalkowski ${ }^{2,3}$, Lars Witell ${ }^{2,4}$, and Anders
}

Gustafsson $^{4}$

\footnotetext{
${ }^{1}$ Nottingham University Business School, Nottingham, UK.

${ }^{2}$ Department of Management and Engineering, Linköping University, SE-581 83 Linköping, Sweden

${ }^{3}$ Department of Marketing, CERS - Centre for Relationship Marketing and Service Management, Hanken School of Economics, PO Box 479, FIN-00101 Helsinki, Finland

${ }^{4}$ CTF Service Research Center, Karlstad University, SE-651 88 Karlstad, Sweden
}

\begin{abstract}
The traditional firm and product-centric view of platforms is changing. Platforms are increasingly developed around value that is co-created with a network of actors. In such settings, lead firms shape their environments and develop value platforms through network orchestration. This study examines how lead firms mobilize network relationships to support and build novel value platforms. The research adopts a multiple case study methodology, investigating the development of six value platforms in network settings within Europe. A large-scale interview program over several years was conducted. The findings unravel practices constituting four overarching network orchestration mechanisms in the value platform development context; envisioning, inducing innovativeness, legitimizing, and adjusting. The study explains the relationships and interplay between the orchestration mechanisms and articulates theoretical and managerial contributions.
\end{abstract}

Keywords: value platforms, network orchestration, mechanisms, business networks, valuecreating systems

This is a so-called personal version (author's manuscript as accepted for publishing after the review process but prior to final layout and copy editing) of the article. Readers are kindly asked to use the official publication in references.

Original article:

Perks, M., C. Kowalkowski, L. Witell, and A. Gustafsson (2017), ’Network orchestration for value platform development," Industrial Marketing Management.

https://doi.org/10.1016/j.indmarman.2017.08.002

Copyright: Elsevier www.elsevier.com 


\section{Introduction}

Increasingly, the competitive advantage of firms stems from platforms rather than product portfolios or standalone offerings (Thomas, Autio, and Gann, 2014). Platforms are ascribed to the success of high-tech companies such as Apple, Google, Intel, and Microsoft (Cusumano and Gawer, 2002; Gawer and Cusumano, 2014; Meyer and Lehnerd, 1997). They enable the co-creation of value among network members, through which the lead firm (and other network members) can achieve business growth and competitive advantage (Gawer and Cusumano, 2014; Nambisan and Sawhney, 2011). Several academic streams have studied the platform concept, including technology strategy (Cusumano and Gawer, 2002; Meyer and Mugge, 2001), operations management (Huang et al., 2007; Meyer and Lehnerd, 1997), product innovation (Nambisan and Sawhney, 2011; Simpson et al., 2005; Sköld and Karlsson, 2007), industrial economics (Armstrong, 2006; Evans, 2003), marketing (Chakravarty et al., 2014; Sawhney, 1998; Sawhney et al., 2005; Sridhar et al., 2011), and information systems (Lusch and Nambisan, 2015).

The platform concept has traditionally been technology and product-based, located within complex system industries (Simpson et al., 2005; Gawer and Cusumano, 2014). Platforms are however shifting towards a value and network-centric notion in that they evolve from the joint actions of network actors rather than the features and attributes of products (Lusch and Nambisan, 2015). This study is concerned with such value platforms. These are dynamic configurations of tangible and intangible resources that act as foundations for value-creating systems (Parolini, 1999), upon which network members co-create value through a set of specific activities. In network settings, lead firms (platform leaders) shape their environments and orchestrate the network to further develop the value platform (Gawer and Cusumano, 2014). Such lead firms can initiate value platform development and support their networkcentric emergence and reconfiguration over time (see also Möller and Rajala, 2007; Möller and Svahn, 2009).

This study puts attention to the way lead firms orchestrate the network for value platform development. It focuses on central network actors that strive to configure network relationships to support and build a novel value platform. It adopts the view that the lead firm is capable of intentionally influencing and managing its network for such ends (Dhanaraj and Parkhe, 2006; Hinterhuber, 2002; Lorenzoni and Lipparini, 1999; Möller and Svahn, 2006; Müller-Seitz, 2012). The research aims to delineate and explain lead firm network orchestration for value platform development in network settings. More specifically, the 
research seeks to identify network orchestration mechanisms, along with underlying practices, and their interplay in value platform development. An orchestration practice is an observable, repeated and routinized single or set of activities of the lead firm related to the development of the value platform. An orchestration mechanism is an overarching assembly of practices that produces an effect on the value platform development, which is not inherent in any one of the practices alone. We are interested in intentional and purposeful network orchestration practices and mechanisms.

The paper progresses as follows. The first section introduces the theoretical underpinning of the study by drawing on two core concepts; network orchestration and value platform, and discusses how they relate to each other in the context of value platform development. The study's multiple case study methodology is then detailed, putting particular attention to the framing and explanation of the data analysis around practices and mechanisms. The findings follow which unravel and demonstrate a complex array of network orchestration practices. Further analysis derives their association with four overriding network orchestration mechanisms that are shown to underpin the construction of value platforms. The connections and interplay between these mechanisms are elucidated. The discussion articulates and discusses three contributions and concludes with implications for management and further research.

\section{Theoretical background}

\subsection{Network orchestration}

Network orchestration is the process of assembling and managing an inter-organizational network to achieve a collective goal (Paquin and Howard-Grenville, 2013), in which the role is accepted by the other network members (Müller-Seitz, 2012). Prior research within marketing and organizational studies have distinguished networks that are intentionally orchestrated from networks that are emergent without guidance from a key network actor (e.g., Dagnino et al., 2016; Möller and Svahn, 2006; Ritter et al., 2004). In contrast, research on orchestration of intentionally created networks assumes that the lead firm is able to purposefully influence and manage its network (Dhanaraj and Parkhe, 2006; Hinterhuber, 2002; Lorenzoni and Lipparini, 1999; Müller-Seitz, 2012); that is, intentional networking 
through deliberate activity ${ }^{1}$. It resonates with studies of networks that adopt an actor-defined perspective, such that a central network actor strives to configure its business relationships through networking activities (e.g., Jarillo, 1988; Kowalkowski et al., 2013).

If networking activities are conducted in a routinized way (Reckwitz, 2002) we refer to them as practices. Consistent with research within industrial network theory (e.g., Möller and Svahn, 2009; Partanen and Möller, 2012) and organizational studies (e.g., Paquin and Howard-Grenville, 2013), we take the view that network orchestration should be understood not as a static structural position but as a set of evolving practices. We refer to such sets of practices as mechanisms. Mechanisms, being an overarching concept (Easton, 1998), describe "an assembly of elements producing an effect not inherent in any one of them. A mechanism is not so much about 'nuts and bolts' as about 'cogs and wheels'...the wheelwork or agency by which an effect is produced" (Hernes 1998, p. 74). Over time, mechanisms - and their underlying practices-may change the lead firm's position relative to other network members. However, individual practices alone may be insufficient to drive change in a network setting. The distinction between mechanism and practice is hence important to make.

The limited influence that the lead firm may have over network members is acknowledged in industrial network theory (Ford, 2011; Håkansson and Ford, 2002), whereas organizational studies of orchestration tend to imply stability and linearity within the network (Müller-Seitz, 2012). Industrial marketing scholars like Anderson et al. (1994) and Ford (2011) highlight the interdependent nature of business relationships within networks and that the ability to influence others depends on such things as the firm's network position. In every relationship, "there is a blend of cooperative and conflicting interests and a well-functioning relationship makes this blend a constructive development force" (Håkansson and Eriksson, 1993, p. 28). As Håkansson and Eriksson (1993) point out, network actors build up structures of resources and activities that cause inertia and reluctance to change. They find that successful orchestration is not only a matter of convincing network members with rational arguments, but also of influencing them by capitalizing on the relationship or even making use of indirect relationships to put pressure on them.

\footnotetext{
${ }^{1}$ These types of networks, being sets of connected exchange relationships (Cook and Emerson, 1978), are often referred to as "business nets" (Möller and Svahn, 2006), "network configurations" (Gemünden et al., 1996), "value constellations" (Normann and Ramírez, 1993), "value networks" (Stabell and Fjeldstad, 1998), "strategic nets" (Möller and Rajala, 2007) or "strategic networks" (Amit and Zott, 2001; Jarillo, 1988). Similar concepts are "innovation network" (Corsaro et al., 2012) and "supplier network" (Håkansson and Eriksson, 1993), although they may also be used to described more loosely coupled systems of independent companies.
} 
Hence, no orchestration activities are controlled by a single network actor. The more capabilities and supporting infrastructure a new business requires, the less likely it is that a single actor can manage the process (Möller and Svahn, 2009). Instead, orchestration represents a collaborative effort within an intentionally formed network (Huxham and Vangen, 2000). Furthermore, previous research suggests that conditions for and aspects of network orchestration differ greatly depending on the type of business network. Möller and Svahn (2006) distinguish between three ideal types of value systems in intentionally created business networks. These span from stable, well-defined systems with high levels of determination and well-known activities/actors, to emerging systems with low levels of determination, new value-creation activities, and a combination of old and new actors. In existing networks that are relatively stable, emphasis is placed on the exploitation of each actor's specialized knowledge. Typically, lead firms strive to achieve high systemic efficiency through integration and coordination. Rather, if the goal is renewal of existing market offerings and business processes, emphasis is placed on balancing knowledge exploitation and exploration. Finally, in new networks, through which lead firms strive to shape markets and create new technologies and businesses, emphasis is placed on sensing and seizing of fragmented and emergent knowledge. As inter-organizational networks are formed and evolve, emphasis shifts from sense making to agenda setting along with the formation of means for collaboration, joint learning, and market growth (Möller and Svahn, 2009; Ritvala and Salmi, 2010). In order to collaboratively mobilize value co-creation and leverage networks, platforms are seen as such means for network members to come together in a more integrated and synchronized way (Gawer, 2009; Palo and Tähtinen, 2011). In the following, the concept of value platform is further discussed.

\subsection{Value platform}

While early perspectives on platforms were firm and internal resource centric, recent conceptualizations increasingly acknowledge the role of network actors in platform development and commercialization (Nambisan and Sawhney, 2011; Thomas et al., 2014). This underscores the critical role of network orchestration in mobilizing value co-creation, which is further supported by marketing research (e.g., Jaakkola and Hakanen, 2013; Partanen and Möller, 2012). In particular, studies of successful firms in informationtechnology intensive industries demonstrate the importance of network centricity when developing platforms. Cusumano and Gawer (2002) refer to lead firms as platform leaders that shape their environments and orchestrate their inter-organizational networks. 
In this study, we specifically develop the concept of "value platform". We view value platforms as dynamic configurations of (tangible and intangible) resources that act as a foundation upon which network members co-create value through a set of specific practices. ${ }^{2}$ Analogous with Wernerfeldt's (1984, p. 172) definition of resource, a platform's tangible and intangible resources at a given time could be specified as those resources which are tied semipermanently to the platform. Resources per se are static (Ketchen, Hult, and Slater, 2007). It is the activities of network members that maintain, transform and adapt resources. Hence platform resources are created, activated and given meaning and value by network members Möller and Svahn (2006) conceptually distinguish between the set of activities and the resource configuration upon which the activities are based and we follow this line of logic. Being a configuration of tangible and intangible resources, the value platform concept thus relates to but differs from network-based concepts such as Parolini's (1999) description of “value-creating system" and Möller and Svahn's (2006) view on "value system”, which refer to $a$ set of activities carried out by the network actors. In our study, these activities are akin to network practices (i.e., routinized deeds) and their overarching orchestration mechanisms. In accordance with literatures on platforms we thus make a distinction between the platform as a manageable object and the value co-creation activities enabled by the platform (see Figure 1).

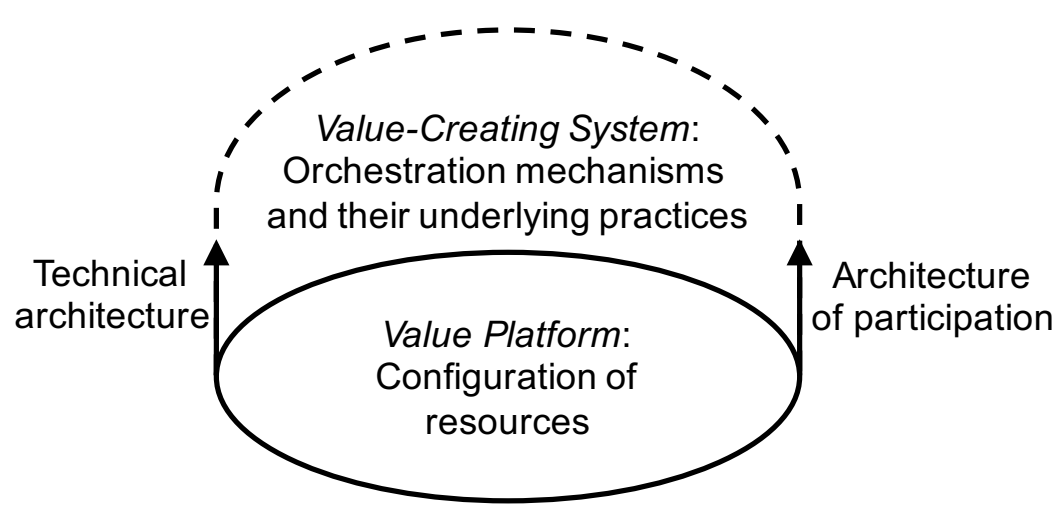

Figure 1: Value platform as a foundation for value-creating system

\footnotetext{
2 Analogous with the three fundamental elements in industrial network theory-actors, resources, and activities - we refer to network members, value platforms (resource configurations), and practices (routinized activities). The characteristics attributed to a value platform has some similarity with what Möller and Svahn (2003) refer to as a "strategic net". Nets are intentional inter-organizational structures which firms design for specific purposes; they are "coalitions of autonomous but interdependent firms that are willing to coordinate some of their actions" (Möller and Svahn, 2006, p. 988). Hence, a net is more related to specific actors in the network whereas a value platform - a concept rooted in literatures on platforms - is more concerned with resources organized in a common structure which facilitates network actors' value co-creation activities (cf., Gawer and Cusumano, 2014).
} 
As illustrated by Figure 1, the platform frames the value creation and business renewal potential of the network's value-creating system (cf., Möller and Rajala, 2007). Hence, value platforms connect different types of network actors through intentionally created constellations. The value platform concept combines the view of the "platform ecosystem stream', for which the platform is a set of shared technologies and standards, and that of the 'organizational stream' (albeit firm centric), for which the platform is a structure that stores organizational routines (cf., Thomas et al., 2014). Value platforms are hence based on not only a "technical architecture" and other tangible resources (as in the case of traditional, firmcentric and product-centric platforms) but also intangible resources. These take the form of an "architecture of participation"; that is, a set of organizational norms, rules, and activities that its connected network members use to coordinate and co-align their actions (Lusch and Nambisan, 2015; Nambisan and Sawhney, 2011). Value platforms can facilitate value cocreation by enabling novel offerings (through innovative combinations of products and services), processes, and other types of knowledge not previously available to the network. Grounded in service literature and its focus on value in use (Macdonald et al., 2016; Vargo and Lusch, 2008), this definition suggests that the value of the platform is determined by the network actors based on the platform's perceived ability to facilitate (or hinder) achievements of the actors' goals.

The concept of value platform resonates with the migrations taking place in many industries as firms transition from producers of superior products and services to co-creators of superior value-in-use (Kowalkowski, Gebauer, and Oliva, 2017; Raddats et al., 2017). Here the lead firm takes a larger responsibility for not only improving value creation in customers' businesses but also in managing interdependencies with other network members (Windahl and Lakemond, 2006). A value platform should bring clarity to the way its network members come together to co-create value and share the value captured among themselves. This is particularly important in cases where the lead firm, which is responsible for the platform development efforts, relies on other actors but has limited ability to influence them.

\subsection{Network orchestration for value platform development}

Literature on platforms suggests that lead firms need to devise and implement an appropriate architecture to enable novel offerings and coordinate network actors (Eloranta and Turunen, 2016; Nambisan and Sawhney, 2011). Gawer and Cusumano (2014) regard network-centric platforms as manageable objects and the result of deliberate managerial decisions and actions. In order to develop and manage the platform, network orchestration is required. Even 
if the lead firm is the principal actor orchestrating the network, network partners also potentially play a vital role in the development of the value platform. Hence the lead firm but also other network actors enhance, change, and redirect the value platform over time (cf., Eloranta and Turunen, 2016).

Table 1 shows exemplars of empirical and conceptual work on network and platform management. While there are many similarities between key practices for network and platform management, research on assembling and managing inter-organizational networks often takes a process perspective, elaborating frameworks with interlinked process stages. Research on platform leadership, on the other hand, does not necessarily distinguish specific stages when discussing effective practices. Given its explicit focus on platforms and their underlying technical core, it is of no surprise that practices concerning technical architecture and other tangible resources are more pronounced in this stream of research (e.g., Gawer and Cusumano, 2014). In both streams of research, practices supporting an architecture of participation for coordinating and aligning the actions of network members are evident. However, research on assembling and managing inter-organizational networks (and industrial network theory in particular) more comprehensively discusses such practices, emphasizing the importance of building commitment (Järvensivu and Möller, 2009) and legitimacy (Dagnino, Levanti, and Li Destri, 2016), and developing a social contract (Mouzas and Naudé, 2007) among actors. In addition, it emphasizes lead firms' roles in not only ensuring value appropriation among these actors but also in facilitating the activities needed for end customers' value creation (Partanen and Möller, 2012) such as exchange and co-creation of specialized knowledge (Lipparini, Lorenzoni, and Ferriani, 2014). Despite differences in the levels of analysis, theoretical frameworks, and terminology used, Dagnino, Levanti, and Li Destri (2016) find that such traits are common in all studies of network orchestration.

\section{- Take in Table 1 here -}

As a network evolves, the lead firm faces a growing number of orchestration challenges arising from the need to create and capture value for its network members. This is particularly acute when a network is responsible for novel activities of which prospective network members lack prior experience. For instance, the orchestrator must balance its efforts to cultivate serendipitous interactions that could lead to fruitful relationships with more deliberate relationship management activities with established network members (Paquin and Howard-Grenville, 2013). The lead firm may also need to build legitimacy by convincingly demonstrating value throughout the development of the novel platform, for its existing and 
potential network members. Legitimacy can act as a constraint on organizations (Dowling and Pfeffer, 1975) but is crucial for the success of new business initiatives (Zimmerman and Zeitz, 2002) such as when new offerings and technologies need to be embraced across several organizations (Suchman, 1995). Legitimacy is portrayed as an operational resource that firms extract from their network and that they employ to achieve their goals (Suchman, 1995). In a business network, the legitimacy of a firm is linked to its activities and its employment and integration of various types of resources (Dacin et al., 2007), such as platform development.

Overall, the critical role of orchestration is acknowledged for establishing and managing inter-organizational networks (Möller and Rajala, 2007; Möller and Svahn, 2009; MüllerSeitz, 2012) and a growing body of literature addresses platform dynamics (Eloranta and Turunen, 2016). In our empirical work, we seek to build on this knowledge by eliciting and explaining the orchestration practices by which lead firms influence and manage their network in developing novel value platforms.

\section{Methodology}

While studies of platform management are extensive, empirical research on network orchestration for platform development is still nascent. To contribute to theory development on the value platform concept, the study was performed following an exploratory multiple case study approach (Eisenhardt, 1989). Case study is a research strategy focusing on understanding the dynamics present within a single setting (Yin, 2014; Eisenhardt, 1989). The study's focus on the development of value platforms through lead firm network orchestration provides challenges since the study object is not a bounded or clearly defined system (Piekkari et al., 2010; Yin, 2014). Since value platform is an emergent theoretical concept, we wanted to study multiple and varied empirical cases. Following Eisenhardt and Graebner (2007), we adopted a multiple case study methodology due to the ability of qualitative data to explicate complex social processes.

To capture network orchestration mechanisms and underlying practices, studying the cases over a long period was important. We interviewed the key respondents several times over time, complemented by interviews with additional network actors (Leonard-Barton, 1990). The use of longitudinal case studies enabled us to investigate how network orchestration practices build on each other and change over time (Eisenhardt and Graebner, 2007). Multiple case studies contributed both to a fine-grained understanding of the interfaces 
between the value platform and the network as well as to identification of patterns in the interplay between different network orchestration mechanisms.

\subsection{Case selection and data collection}

The value platforms were selected as cases. We used a criterion-based theoretical sampling approach, and initially defined criteria regarding adherence to our theoretical definition of value platforms in order to identify and select suitable cases (Eisenhardt, 1989). Based on our view of value platforms as (1) dynamic configurations of tangible and intangible resources; on which (2) network members can co-create value through a set of specific activities; we identified a number of potential value platforms. The value platforms varied in complexity, which enabled us to identify a range of lead firm network orchestration practices. Hence, the value-creating systems (Möller and Svahn, 2006) also varied, from renewal of existing systems to the emergence of new ones. In addition, the choice of cases was based on full access to the lead firm and access to other network actors and that the addition of the case would add variability to our view of value platforms. In the case studies, the research focused on identifying the orchestration practices of the lead firm. Ultimately the lead firm benefits if the platform progresses to incur network value.

Six value platforms fulfilled the selection criteria adherence and access. The names of the value platforms and the lead firms have been changed to protect the confidentiality of the participating firms. The value platforms are called Bedcare, CareHealth, CoffeePro, FleetServices $^{3}$, Insure, and Telenav. The case lead firms come from Western Europe, representing different industries. Table 2 provides a description of each lead firm and value platform.

- Take in Table 2 here -

Data collection was adjusted to the specifics of each case. In all 126 interviews were conducted across the six value platforms. Multiple interviews were performed over time, between two and six times, with 13 key respondents in the lead firms. Other network actors were interviewed to get an alternative perspective on the lead firm orchestration practices. In addition, this provided an understanding of the effects of network orchestration on other actors connected to the value platform. Key respondents among network actors were identified through snowball sampling (Coleman, 1958).

\footnotetext{
${ }^{3}$ A study of the evolution of the value-creating system in the FleetServices case has been published by Kowalkowski, Kindström, and Carlborg (2016).
} 
To aid data collection and ensure consistent interviewing procedures, an interview guide was developed. This focused on the theoretical concepts of value platform and network orchestration (Miles and Huberman, 1984). The first part put attention to the value platform and the network, followed by questions about the development of the value platform over time focusing on the network orchestration practices of the lead firm. The interviews lasted 30-190 minutes, with the majority lasting 60-120 min. Most of the interviews were recorded and transcribed. Field notes were taken in the cases when respondents asked not to be recorded.

The interview data was complemented with different types of secondary data. In Insure, this included minutes of meetings, accounts, copies of documents, various procedure and review documents, service scripts, copies of correspondence between network actors, website designs and brochures. In FleetServices, this included a rich repertoire of internal documents (including platform strategy and management plans and documents targeted at dealers and customers) and public documents (press releases, web sites, social media). Through site visits, facilities tours and observation of meetings, the researchers were able to observe employees at work and communicating with other actors in the network. Field notes were developed as a further source. In addition, data was collected through lead firm-initiated workshops where multiple representatives from different actors participated. In other cases, such as Bedcare, CareHealth, CoffeePro, and Telenav, the interviews provided most of the data. Secondary data, including internal documents (sales guides, transition guide from old to new version of platform, and training programs) and public documents (technical guides, marketing material, apps and videos) complemented the interview data. Table 3 provides an overview of each case and data collection details. Further details about data collection in each case is available in an appendix.

- Take in Table 3 here -

\subsection{Data analysis}

Data analysis was performed in three stages. First, we performed a within case analysis to identify the context, the content of the value platform and the key network actors. We also identified and described how the value platform and the network developed over time. Then we focused on the identification of lead firm network orchestration practices. We used the interviews with the key respondents to identify lead firm network orchestration practices and their role in the development of the value platform. Data from other value platform actors 
was used for validation of lead firm orchestration practices and to identify the effects of these practices on the value platform and the different network actors. When these interviews revealed additional information, we validated the new information with the lead firm representatives. Secondary data was used to validate these initial insights.

Second, we performed a cross-case analysis (Yin, 2014). To increase internal validity and make sure that the meaning of the network orchestration practice had not changed in the cross-case analysis, each case was revisited and coded with the identified network orchestration practices. Delving deeper into the impact and nature of the network orchestration practices in the cross-case analysis enabled us to unravel the orchestration mechanisms, which are higher-level constructs. These are overriding mechanisms (Easton, 1998), unveiled from the myriad of observed network orchestration practices. These underpin and explain the development of value platforms in network settings and act as an assembly of practices producing an effect not inherent in any one of the practices alone. Four overarching network orchestration mechanisms emerged that are key for value platform development. We made cross-case observations about how each network orchestration practice related to these mechanisms. The effectiveness of the network orchestration practices was coded as facilitating or impeding, according to how it influenced the development of the value platform. The network orchestration practices across the cases were then clustered in terms of their association with each of the identified mechanisms. Through interpretation and crosschecking by four experienced researchers, patterns emerged in terms of the way each mechanism influenced the development of the value platform.

Third, we analyzed the relationships between the four orchestration mechanisms. We disentangled the deployment of the orchestration mechanisms by the lead firms and inferred the within-case interplay between them. We then analyzed how these identified relationships between the orchestration mechanisms played out across the cases. This allowed us to further pinpoint and substantiate the major relationships between the orchestration mechanisms.

\section{Findings}

The findings are divided into two parts. In the first section (4.1-4.4) we depict and explain the within and cross-case study practices and overarching orchestration mechanisms. In the second section (4.5) we show the interplay between the mechanisms. 
There is an array of different practices through which the lead firms in our cases orchestrate the network for the development of the value platform, but not all practices are found in each case. The practices manifest themselves differently across the cases and can facilitate or impede the way the value platforms develop. Following the analysis explained in the method section, practices cluster around four higher-level orchestration mechanisms. These are:

- Envisioning network value for the platform. This mechanism entails envisioning the potential value of the platform for its members and understanding how the network can collaboratively build and enhance this value.

- Inducing innovativeness of network members towards the value platform. This mechanism is characterized by investments and activities of the lead firm to support and direct the innovativeness of network partners towards value for the platform.

- Legitimizing the value platform through the network. This mechanism relates to both value platform legitimizing by the lead firm, and also to inducing the network to legitimize the value platform.

- Involving the network in organizational adjustments towards the value platform. This mechanism is characterized by network-influenced adjustments of the lead firm's internal structures and routines towards the emergent value platform.

In the following section we explain each mechanism, show the underlying practices associated with each mechanism and demonstrate the facilitating or impeding nature of the derived practices. Illustrations from the cases are provided throughout the text and table 4 provides further evidence of the practices within the cases.

- $\quad$ Take in Table 4 here -

\subsection{Envisioning network value for the platform}

The study findings show that the identification, by the lead firm, of future platform value likely to accrue from the network is an important orchestration mechanism. Prior research recognizes the need of lead firms to attract valuable partners by communicating the credibility and attractiveness of business ideas (Cattani and Ferriani, 2008; Human and Provan, 2000). Scholars have proposed that lead firm co-ordination activities to intentionally foster the emergence of a whole network vision and identity should be in place in early stages of network formation (Dagnino et al., 2016). Network visioning can drive such lead firm activities, which has shown to lead to change or inertia (Laari-Salmela et al., 2015). Whilst such research largely adopts the network as the focal object of the vision, this study uncovers practices related to envisioning how the network might develop, as yet, unrealized value for a platform. As platforms are at early stages of evolution, the findings show that this can be 
problematic. We show how anticipating network-led platform value requires both a future and a network orientation. However, this may be beyond many firms in the early stages of value platform development. Study findings related to both the facilitating and impeding nature of lead firm practices associated with this mechanism are provided below.

\subsubsection{Facilitating practices}

\section{Envisioning complementary value from network}

The cross-case analysis shows evidence of practices to identify where complementary future value is likely to emerge. This means going beyond the core platform, even envisioning value coming from other seemingly non-related businesses of the network partners. The findings show how lead firms adopting this practice engage in shaping nascent ideas and areas, which are ambiguous and ill defined. In the Insure case, for instance, the lead firm predicted in early stages of its platform development the nature of complimentary resources that could accrue from external partners. For example, it contacted the Association of Senior Police Officers to jointly craft incremental value around the insurance platform, whereby police are automatically alerted in a vehicle emergency. The police created new resources by setting up novel criteria for how and when to be notified. The lead firm subsequently exchanged resources by providing them with information about incidents and causes related to the positioning and signage of speed cameras. Police then reconfigured their own resources and processes around this added value. The lead firm at FleetServices adopted early envisioning practices by investing in visioning resources. These took the form of workshops on selected markets with leading dealers and customers. These increased shared understanding of each party's needs, communicated potential value to all actors and enhanced the lead firm's understanding of service provision.

\section{Crafting of network roles to enhance the platform}

The findings show evidence of early understanding and nurturing of network roles specifically oriented towards the development of value for the platform. Typically the lead firms, adopting this practice, take charge in the network and identify an array of roles ranging from specific development tasks to dissemination, advocacy and influencing roles. In CareHealth the lead firm ensured early access to 'the debates we need to be in' (lead firm Marketing Manager) and the people likely to lead these and take on advocacy roles. The business development manager of the lead firm commented about a key individual ultimately very valuable to the platform development: "She is ultimately the person who is driving it 
forward. She is a very senior lecturer in infection control next to Guys and Saint Thomas hospital in London." She explained how the lead firm hosted a series of events where it was able to amass critical resources and "bring all these people together, who are forum leaders, and it allows us to be seen as involved in the conversation as well, rather than being a supplier of product." The lead firm purposefully invested in a new coordinating resource, namely a safety improvement facilitator role as a "conduit between the patients and us - to bring their voice to us," commented a key respondent. Similarly, the lead firm deployed scouting techniques for potential partners, inviting nurses and clinicians to join the network.

Identifying value misalignments within the network

Facilitating practices encompass not only identifying value potential but also value misalignments within the network. Here there is evidence of lead firms identifying network partners whose potential value is likely to be misaligned with the platform. In the Insure case, for example, the lead firm was uncertain of the relationship management resources of an existing network partner. Increasing the number of customer touchpoints was a critical element of the platform value and this key partner did not have the prerequisites to develop customer relationship-oriented resources. It was unlikely to invest in new resources aligned to the same value vision as other network partners and its likely disrupting force was envisioned early on.

\subsubsection{Impeding practices}

\section{Product or technical focus of platform communicated to the network}

Two of the case lead firms showed evidence of an inability to understand or articulate the complexity and intangibility of the developing value platform resources. This meant potential value was communicated to the network in terms of tangible product attributes. This, in turn, constrained the ability of the network to creatively experiment with platform development ideas. One example of this is Telenav, where one of the global product managers explained how they struggle to define the intangible nature of the platform value and translate this into monetary value to the customer. Even several years after the first generation of platformbased services was launched, "we really struggle to understand how can we sit in front of the customer and ask them to pay us for a service" (senior manager at Telenav).

Adherence to pre-existing roles of network members 
Many of the lead firms from the case studies rigidly stuck to existing ways of managing the network as the value platform emerged. This seems a natural response where there is a high degree of ambiguity over potential new lead firm and network roles vis-à-vis the platform. However, it appears that sticking to known and familiar roles can reinforce a product/technical focus for the emergent platform. For example, the lead firm in Telenav did not attempt to understand the value potential of the network. It failed to anticipate the new and critical role of specific existing resources, namely dealers, in the eventual success of the platform. The Service Director explained, "While we had some customer input, much of it was our own thoughts and beliefs. We thought we understood how a dealer and a customer business works and then we built a "one size fits all" and we ended up with a solution that was not $100 \%$ good for anybody." At FleetServices the lead firm recognized the need to achieve value alignment, but it failed to invest early on in practices to change the scope of a critical actor; the dealers. Unwilling to take on a more extensive service role, dealer behavior proved to constrain, for a long period, the development of the value platform.

\subsection{Inducing innovativeness of network members towards the value platform}

This mechanism is characterized by lead firm investments in resources to induce innovativeness by the network; by carrying out innovation activities on behalf of the network; and by sharing pivotal platform knowledge-based resources. In network orchestration, lead firms mobilize organizations towards the network (Möller and Svahn, 2009). Intentional management of the network requires a capacity to intervene with other network partners and shape the overall conditions of the way the network operates (Muller-Seitz and Sydow 2012; Paquin and Howard-Grenville, 2013). In the platform-constructing context, a network-led approach means letting go. It means inducing network members to provide new value for the platform as perceived and evaluated by themselves.

\subsubsection{Facilitating practices}

\section{Freely revealing platform knowledge}

The case studies showed some evidence of investments in processes or systems to facilitate easy network access to platform knowledge-based resources. Platform knowledge-based resources encompass information about the platform itself as well as about lead firm activities and capabilities. Information about what the rest of the network was doing in relation to the platform was also important. The lead firm in the CareHealth case understood 
the pressures and workload of their customers facing reduced workforces, so supported their customer partners by providing free of charge infection control audits. This was a valuable aspect of the platform value. "We're actually removing a burden from the customer teams themselves," commented an employee in the lead firm. The lead firm also recognized early on the need for timely sharing of platform information among network members. It invested in speedy response to network members' innovation problems: "sometimes a problem exists on the spot, and you didn't think of it before, so you would like it to be quick. With Richard and all the other employees of Healthcare Co, including technical support, I am provided with an answer within a day or even a few minutes" (Senior Manager Respondent, Healthcare $\mathrm{Co})$.

Investing in processes to support network innovation advances around the platform

The evidence shows the development of processes to support network-centric innovation oriented towards the platform. These typically entailed direct investment in platform-oriented resources for the network, such as materials, facilities, ICT and engagement portals. However, some of the lead firms went beyond the boundaries of the platform to allow network-centric experimentation for new unanticipated value to surface. There was even evidence of such support encouraging the business growth of network partners beyond the focal platform. Insurance $\mathrm{Co}$, for example, invested in resources to support a racing day for the best performing customers. Racing was the passion of its installation company network partner. This induced the partner to commit resources to further develop and establish this initiative, which in turn became part of the platform value. The lead firm also encouraged the installation company to instigate box installation at its own premises on Saturdays (rather than at customers' homes). This provided the network partner with opportunities to sell additional services and products (e.g. radios) and expand its business beyond the platform. The lead firm in CoffeePro invested in a new resource (a coffee academy) for its network. Free resources, such as training in the process of delivering a good cup of coffee, were provided. Environmental sustainability was emphasized, which was a critical underlying value for the platform. This subsequently directed key members of the network towards resource investments which stressed sustainability, aligned to the platform value.

\subsubsection{Impeding practices}

Retention of platform knowledge 
Where the lead firm does not share platform details, network members can deem the platform ambiguous. The cases showed evidence of practices to retain platform knowledge. In the FleetServices case, for example, the lead firm failed to communicate the nature of the platform to its dealers, despite its efforts to envision network value. Its dealers struggled to recognize how value was derived in the platform: "what the customer pays goes to the manufacturer. How are we then going to earn money? I doubt this new service will give me increased service sales income through preventative maintenance" (Owner of dealer firm connected to FleetServices). Hence the dealers were constrained in their ability to direct resource investments around the platform.

Firm-centric assessment of capabilities and resources of network members

Some of the lead firms in the study retained fixed and firm-centric perspectives of the capabilities and resources of their network members. In assessing the way the network could add value to the platform they typically considered only traditional and existing resources and skill sets of their network. This thwarted their ability to appropriately direct and support novel value and network-centric innovativeness around the platform. In the Telenav case, the lead firm had profound knowledge of the competences and engagement of its independent dealers when it came to the product business. However, managers lacked and failed to develop in-depth knowledge of dealer capabilities for seizing platform-enabled business opportunities.

\subsection{Legitimizing the value platform through the network}

Legitimizing the value platform appears as a third critical mechanism. Operating within interfirm networks requires lead firms to build legitimacy. Research has shown that legitimacyconstructing activities can entice and assemble organizations around the network (Human and Provan, 2000; Möller and Svahn, 2009; Dagnino et al., 2016). It is always difficult for firms to demonstrate and justify a network-centric development approach to outside stakeholders. Having existing formal ties and a prominent position in the network can strengthen the lead firm's legitimacy, particularly in early stage network formation (Möller and Svahn, 2009). However, in a platform-constructing context the study findings show that legitimacy needs to be built for the platform value and the network. When the value of the platform is configured through the network and dynamically evolves, legitimizing or demonstrating such value is particularly onerous. The evidence shows that this mechanism provides powerful advocacy for both the value platform and the network itself. 


\subsubsection{Facilitating practices}

Developing and communicating metrics around emergent value

The findings show ample evidence of the lead firm providing performance metrics of elements of the value emanating from the network. Where these are then communicated to the network, such practices provide strong legitimacy of the value platform to the network. This further encourages network members to work on enhancing the value. CareHealth utilized network members to provide performance metrics demonstrating the emergent value of the platform. It developed and deployed a new disseminating resource based on a structured process of success stories, spread by distributors and consultants. These were stored and made available on an online resources portal. The marketing manager explained how this also serves as a conduit to explain and promote the platform value. He commented; "it presents a consistent message about what we are aiming to do. Historically it has been fragmented - everyone doing and making their things a bit, using their creative freedom and we don't end up with anything consistent. We are now addressing that..." (Marketing manager, CareHealth case). Similarly, the lead firm in Bedcare developed tangible performance metrics, such as reduced carbon footprints and the reduction of multidrugresistant bacteria. Further, these performance metrics were tailored for network partners and internal senior management, indicating different value of the platform for each stakeholder group.

Demonstrating the platform value to others beyond the network

Some of the lead firms went beyond the immediate network to legitimize the emergent platform. Firms adopting this practice typically made use of existing communication resources, such as social media (e.g., Facebook and YouTube), to demonstrate the value platform to potential users outside their networks. For instance, the FleetServices lead firm made use of YouTube to give publicity to testimonials from its pilot customers and to explain the new fleet management concept to a broader audience. This practice also served to change the perception of the firm among potential network members, towards a more tech-savvy and service-oriented company.

\subsubsection{Impeding practices}

Generation of inappropriate value platform metrics 
The findings show several lead firms developing poor quality metrics to assess new and emergent platform-based resources. Such indicators were weak in their ability to convince others of the value of the emergent platform. Several lead firms in the case studies failed to tailor metrics to diverse stakeholders. Instead, they developed a standardized blanket set of metrics. Hence the value of emergent platform-based resources was not apparent to many network members. In Bedcare, for example, the lead firm developed platform metrics that demonstrated current value based on existing resources; that is, single patient bed care facilities. It failed to develop medical evidence of the future value of the platform when scaled up to an entire hospital. In the CoffeePro case, the lead firm lacked metrics to support its envisioned move out of a pure cost competition to a value competition, which was core to the platform. Similarly, the lead firm in the Telenav case was unable to provide convincing business illustrations of the platform value. Several of its network members considered the available platform data of poor quality, and the communicated metrics did not address the most pressing customer needs. This led to high levels of resistance from dealers (and several internal units) to the new platform and they failed to actively promote the new platform. As the global product manager commented, "you would not believe the resistance we are meeting-it's a hell of a bell."

\subsection{Involving the network in organizational adjustments towards the value platform}

The fourth mechanism is characterized by network involvement in lead firm adjustments towards the value platform. Such adjustments involve shifts in existing resources, routines and structures towards the emergent value platform. Previous research has shown how lead firm managers employ practices to improve the efficiency and speed of resource exchange processes (Provan and Kenis, 2008). This often necessitates changes to existing ways of working. Managing and mobilizing the network towards the value platform can create network overload (Hansen, 2002) and disrupt existing routines of the firm. Adaptation of existing routines is therefore required to achieve better fit with the emergent network-led value platform. Our study shows how network participants can support such adaptations.

\subsubsection{Facilitating practices}

Seeking advice from network on potential organizational adjustments

The findings show evidence of lead firms seeking advice from their network about necessary internal resource and capability investments. By working with its network, Insure was able to unravel internal gaps to support the emergent value platform. One of their managers 
explained; “Actually it made us realize there's holes in what we're doing. We've had to sort of fill the holes. Our network partner said "look they're (customers) asking these sorts of questions. We've got to give them that sort of information" (manager, Insure). This led to investments in new resources, namely staff to manage an internal process to analyze touchpoints with customers. The Insure lead firm re-orientated its strategy towards new customer co-creation value: "What we are moving to is a strategic approach to the interactions with the customer. What we don't want is ad-hoc decisions that have been taken because every month they could change and as opportunities come up you want to plan forwards and have a number of well thought our mechanisms to do that. We're taking on board what our suppliers and customers are saying" (marketing manager, Insure). Other resource investments included a new service center in order to increase customer interactions, which in turn was core to its new platform. Hospital Solutions Co also sought input from its broader network before gradually shifting resource investments from competency building in manufacturing towards building service provision and sales capabilities.

Verifying intended adjustments with network members

The findings show some evidence of lead firms testing and verifying such adjustments with the network. This practice entailed, for example, network-coordinating resources, such as setting up working groups to harness network viewpoints on future investments. It involved sharing future intentions and plans with the network. HealthCare Co, for example, undertook several focus groups with key actors in the network to garner views before committing new resources to the platform. As a senior manager commented "if we got a bad reaction from them it made us think more about doing it."

\subsubsection{Impeding practices}

Fixing resources and routines around original value

The findings show evidence of practices designed to maintain the status quo around the original platform value. Frequently the lead firm was hence unable to amend resources and routines or be flexible to new value coming from the network. The problem for networkcentric value platforms seems to be that repercussions for the lead organization are greater than for more discrete product or service projects. The whole organization needs to get behind a network approach and the findings show that this can be problematic. At Telenav, the lead firm developed a first version of the platform on resources fixed around a technical architecture. These resources proved difficult to modify and adjust as the emergent value for 
the network became apparent. Only after the technical architecture was replaced could many of the initial technical limitations be overcome. Furthermore, the existing organizational structures fixed around original product-oriented value made necessary shifts onerous. For example, the managing director of a sales company initiated a vanguard app-based service but had to go through cumbersome processes to get approval from the corporate IT division. Because of all the bureaucracy, he was told by his superior to proceed by "flying below the radar" to avoid losing the first-mover advantage. Evidently, the rigid centralized processes did not accommodate for such rapid, technology-driven resource adaptation in the local organization.

In conclusion to this section of the findings, table 5 depicts a synthesis of the cross-case comparison. It portrays the different orchestration mechanisms, and underlying practices, across the cases and shows their application in each case. Figure 2 provides a visual corollary of the conceptual analysis provided.

- Take in Table 5 here -

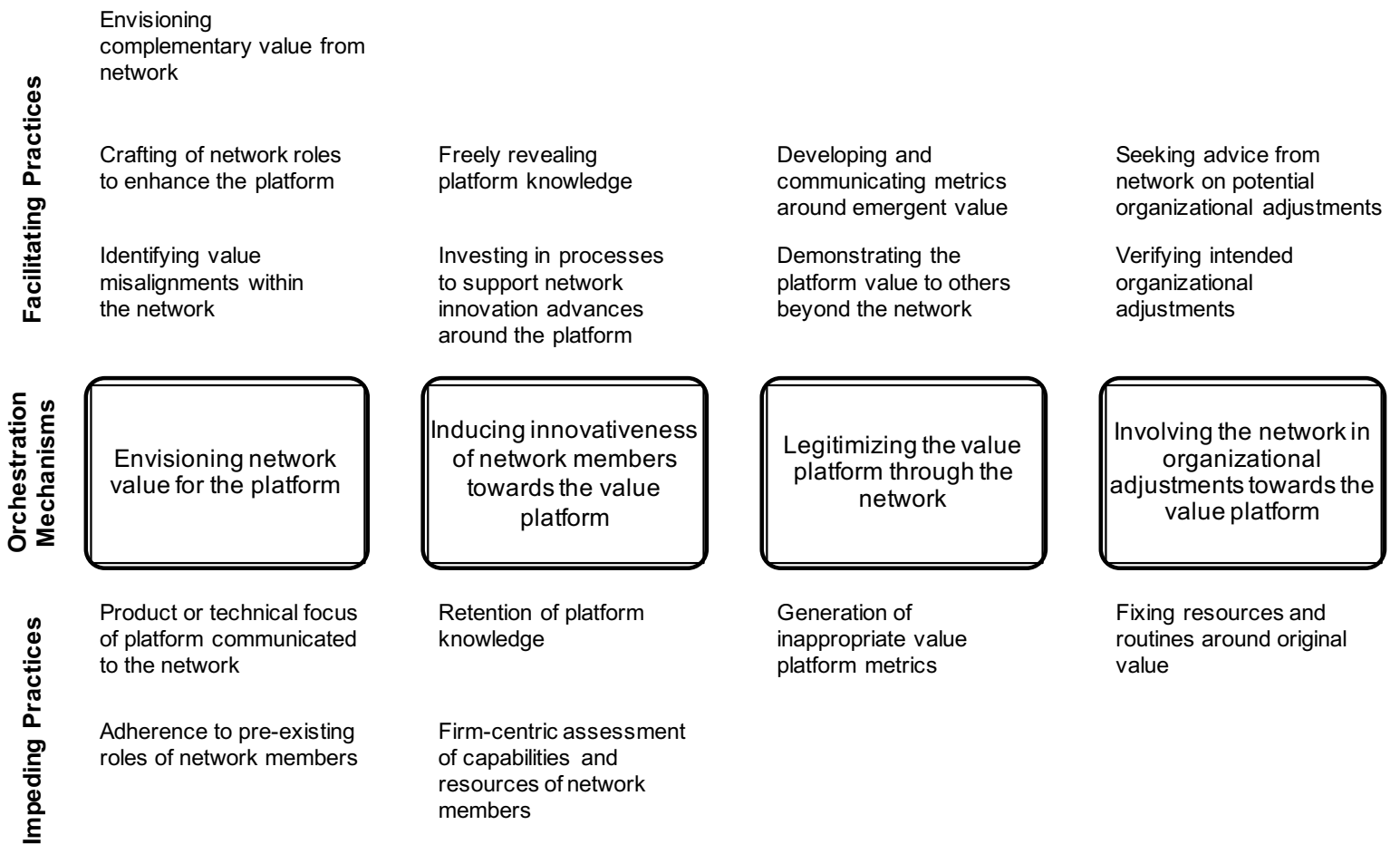

Figure 2: Orchestration mechanisms and nature of associated practices 


\subsection{Relationships between the orchestration mechanisms}

The findings show that we cannot consider the derived mechanisms in isolation. It is the connectedness between them that is important in explaining the effectiveness of the way lead firms orchestrate the network for value platform development. The mechanisms can build on and strengthen each other. It is also the case that certain mechanisms need to be in place for the other mechanisms to operate. In this second section of the findings we explain the major relationships between the mechanisms that appear to critically impact on the development of the value platform. Supportive evidence from across the cases is given.

\subsubsection{Relationship between envisioning and inducing innovativeness}

The results provide strong evidence that envisioning supports the lead firm's ability to induce innovativeness of the network around the emergent platform. Setting and communicating a clear vision provides direction for platform-based innovation to occur in the network. The case evidence shows that if the lead firm envisioning is weak or poorly shared, it is difficult to induce innovativeness. Network members struggle to interpret what they should or might do in innovating around the platform. The nature of this relationship is demonstrated in the case evidence;

Insure's powerful CEO had a strong platform vision that was effectively disseminated to the network. This early crafting of a course for the platform development speeded up necessary incremental innovations by key members of the network. This also allowed network members to be confident of the direction of their innovative behaviors. In contrast, whilst FleetofTrucks had a clear vision for the platform, it lacked the resources and experience to share and communicate this, particularly in terms of value to network members. The latter hence struggled to understand and innovate effectively around the platform. Similarly, Bedcare's internal vision was not supported by a shift in internal resources and roles to communicate the envisioned platform development path to the network. This resulted in a time-consuming process to align the network towards the platform. CareHealth Co had weak envisioning and relied heavily on network members to shape the vision and craft out their innovation roles so the lead firm lacked influence and was unable to direct the nature of such innovations. Both Telenav and CoffeeCo, though platform oriented in intent, remained fixated around existing traditional product focus in their early dealing with the network. They struggled to envision how the network could develop value for the platform and to inducing innovativeness from the network. 


\subsubsection{Relationship between inducing innovativeness and legitimizing}

The case study findings suggest a strong relationship between inducing innovativeness and legitimizing mechanisms. As lead firms induce and support innovativeness of the network around the platform, so network members develop platform-oriented innovation outcomes. These provide the basis for performance metrics to legitimize both network and lead firm innovation efforts. These metrics, in turn, provide support and confidence to the network to dedicate further resource investments in the platform. Where the lead firm is weak in inducing innovation, network members are driven to innovate alone without direction from the lead firm. Hence metrics may be misaligned with the platform, which can thwart effective legitimizing around the emergent platform. The findings suggest that the envisioning mechanism underpins this relationship. Effective envisioning supports speedy and platformcentric innovative efforts by the network. Where there is no vision by the lead firm, platformoriented innovation is weak by the network, with a subsequent dearth of performance metrics to legitimize. This is illustrated across the cases;

Insurance Co effectively induced innovativeness of the network, which in turn formed the basis of metrics developed by the network members themselves. Healthcare Co, on the other hand, relied heavily on network members to craft their own innovation roles. Progress metrics from the network were not forthcoming, pushing the lead firm to generate is own tailored performance data with limited network input. FleetofTrucks Co failed to disseminate platform details and metrics, leading to ineffective legitimizing. Hospital Solutions Co, having failed to share the platform vision, was driven to develop its own platform metrics misaligned with the platform value as perceived by the network. Coffee Co recently did a shift in the platform vision; hence, the metrics are misaligned as the vision is getting re-shaped. Finally, Infrastructure Co struggled to induce innovativeness from the network, as the platform vision was communicated in inappropriate technical terms; network members did not value subsequent technical performance metrics, intended to legitimize the emergent platform.

\subsubsection{Relationship between legitimizing and adjusting}

The cross-case evidence suggests that legitimizing can support network-led internal adjustments by the lead firm. Lead firms can utilize metrics, developed by the network, to support and justify internal adjustments. However, the findings show that the envisioning mechanism needs to be in place too. It seems that early envisioning (and sharing the vision) leads to appropriate platform-oriented innovation by the network. This provides platform 
metrics that can be used to garner support and resources from senior management to adapt internal routines and resources to foster further innovation (internally and from network) towards the platform.

The findings show that without shared envisioning, the other network actors are driven to craft their own interpretation of platform value and will innovate independently. This in turn thwarts the development of platform-centric performance metrics, which are not then available to support internal adjustments. A consequence of this is difficulties in convincing senior management of the need to make internal changes to support platform development. The nature of this relationship is demonstrated across the cases;

Insurance $\mathrm{Co}$, the lead firm at Insure, encouraged the network to develop its own metrics and involved them in verifying internal changes in resources and routines. This led to successful internal adjustments towards the emerging value platform. Hospital Solutions Co and Infrastructure Co, the lead firms at Bedcare and Telenav respectively, legitimized in technical terms and the network strained to understand the platform value, resulting in poor innovativeness. Weak network innovation performance exacerbated difficulties in justifying further resource commitments and convincing senior management of the need for internal adjustments. Coffee Co, the lead firm at CoffeePro, whilst supporting its network, has an emergent platform vision and is still stuck to existing internal roles and routines. Healthcare Co spent considerable resources supporting the network around CareHealth, but advances were not aligned to a shared platform and it lacked necessary metrics to garner internal support for additional resources for the platform development.

\section{Discussion and theoretical contributions}

We contribute to research which studies the way deliberately designed and structured business networks are managed (Dagnino et al., 2016; Möller and Svahn, 2006; Müller-Seitz, 2012; Ritter et al., 2004). Specifically, we extend existing knowledge in three ways. First, in line with extant research on network management that unravels orchestration activities critical for success, which differ from hierarchical governance (e.g., Dhanarai and Parkhe, 2006; Järvensivu and Möller, 2009), we delineate how platforms enable value co-creation. Hence, we move from the network itself as the focal unit (Möller and Svahn, 2006) to a focus on the value platform as the foundation upon which the network co-creates value. 
Second, we empirically derive practices constituting four overriding network orchestration mechanisms through which value platforms are developed. Extending the findings of Möller and Svahn (2006), who unravel knowledge and learning mechanisms across diverse business networks, the extant study shows that orchestration mechanisms operate across established and newly formed organizations. Also, previous research has studied intentional network management mechanisms largely to achieve accomplishment of the business idea (Dharaj \& Parkhe, 2006; Owen-Smith \& Powell, 2009; Möller and Svahn, 2009; Dagnino et al, 2016) or to advance the project (Paquin and Howard-Grenville, 2013). In contrast, this study focuses on platform development as the context in which networks are orchestrated. Our contribution lies in pinpointing specific practices, which can both facilitate or impede the way firms orchestrate the network, specifically for value platform development.

Third, building on prior research that has identified interlinked stages and practices for network development and management (Järvensivu and Möller, 2009; Muozas and Naudé, 2007; Partanen and Möller, 2012), we highlight the interplay of the derived orchestration mechanisms. We explain the way such mechanisms are interlinked and relate to each other. This resonates with mechanism-based theorizing in organizational studies: "If a regression tells us about a relation between two variables - for instance, if you wind a watch it will keep running - mechanisms pry the back off the watch and show how" (Davis and Marquis, 2005, p. 336). These theoretical contributions are further explained and discussed below.

Network-driven value platforms present high levels of uncertainty for lead firms. The lead firm is often shifting away from known experiences and capabilities, such as technical expertise. In parallel, the abilities of its network partners to develop the platform may be indeterminate. An ability to envision the key elements of the value platform reduces uncertainty, provides early clarity and supports focused network behavior. The importance of a vision for emerging business concepts has been previously highlighted in industrial network theory (Laari-Salmela et al., 2015; Möller and Halinen, 1999; Möller and Svahn, 2006). Prior research emphasizes the definition and fostering of whole network vision and identity (Dagnino et al, 2016). Early network coordination mechanisms are aimed at spreading the network business idea and its potential value (Möller and Svahn, 2009. In the platform development context, explored in this study, envisioning practices entail moving beyond a business idea to the nurturing of an emergent network-determined value set. Hence, the present research extends prior research since facilitating practices (such as envisioning 
complementary value, role planning, and identifying value misalignments) relate to the ideas underlying the value platform as the focal object of the vision.

This study also puts attention to the way early envisioning influences subsequent value platform development; the relationship between envisioning and inducing innovativeness becomes critical. Gawer and Cusumano (2014) and Nambisan and Sawhney (2011) argue that lead firms should pursue a strong platform vision, such as determining the overall design and basic technical architecture as is the case for network-centric platforms. However, they acknowledge that lead firms are seldom able to predetermine elements of value. In the extant study, we show that if the lead firm too tightly specifies the platform vision, often along technical or product lines, the network is constrained in innovating. Existing literature on platforms (e.g., Chakravarty et al., 2014; Jiang et al., 2005; Sridhar et al., 2011) frequently adopts a technology-based view on platform development or winner-takes-all logic under which companies strive to win the war for product leadership (Cusumano and Gawer, 2002). Indeed, our findings demonstrate that adopting a technical or product-centric vision is likely the easier route for lead firms experimenting with value platforms and struggling to develop novel pathways. Yet, we show that breaking away from traditional firm or product-centric visions and trajectories is crucial in cases where firms pursue growth through novel networkled value platforms.

Prior research has emphasized orchestration mechanisms to appropriate innovation from the network (Dhanaraj \& Parkhe, 2006). In our study we show that firms induce the network to create new value by innovating around the platform. We concur with Järvensivu and Möller (2009) regarding the importance of altering the existing perceptions of network members. Since network members hold knowledge of the value they want and are able to create, an open architecture for participation guided by a vision needs to be in place and disseminated to the network. Network actors need to believe in the shared vision. If not, they lack guidance and can innovate in directions that are misaligned with the platform or change allegiances. Furthermore, they can develop new value, and make internal adjustments, that support other parts of their business, maybe far removed from the platform. We propose that envisioningdeveloping and communicating a shared vision for the value platform-helps the lead firm guide the network towards innovative advances targeted around the emergent platform.

The extant study also stresses legitimizing as a major orchestration mechanism. It puts attention to what lead firms can do to encourage the legitimization of value emerging out of 
the network-centric platform. Networks involve a wide range of actors who can make legitimacy judgments (Bitektine and Haack, 2015; Provan and Kenis, 2008). van Riel et al (2013) proposed that inter-organizational networks achieve legitimacy by evaluating the technical and managerial features of the intended innovation. To convince network members, lead firms capitalize on existing relationships, use objective performance metrics, and influence actors through others (Håkansson and Eriksson, 1993). To date, prior research has advocated legitimacy building around the innovation (van Riel et al, 2013), the lead firm (Dagnino et al, 2016), and the network (Human and Provan, 2000; Low and Johnston, 2010). We extend this line of thinking to the platform development context and show how firms legitimize new reconfigurations around value platforms. Firms become inter-dependent not only on mutually developing the platform, but on legitimizing the platform's value and success. Legitimacy building in the platform development context involves practices related to the development of platform-based metrics that are meaningful to the network. To succeed, dissemination to network participants and beyond to their own networks as well as lead-firm management is required.

The final orchestration mechanism is network-led adjusting. Research has long stressed the importance of amendments to routines to accommodate a network (Huxham and Vangen, 2000). Recently institutionalization of network transformation has come to the fore as a central process of innovation (Vargo et al., 2015). Extant research suggests that institutional change only occurs when a network logic is embraced by its members (Letaifa et al., 2016). The extant study strengthens this body of research in two ways. First, it shows that integrating the network in processes to garner support for and guide internal transformation can support platform-oriented adjustments of lead firms. Second, it explicates the relationship between legitimizing and internal adjustments. Legitimizing through demonstration of the value of the emergent platform helps justify internal adjustments to routines and practices. Where such metrics are lacking, lead firms may stick to old familiar routines and seem unable to convince the broader organization of the need to change. Envisioning underpins this relationship. Development of an early vision ensures that lead firm individuals, along with other actors in the network, are on board. This common vision adds credence to performance metrics. It further supports development of the appropriate co-created platform metrics so that the case for adjustments and platform-based resource commitments is more easily communicated and understood. 
To sum up, the extant study has investigated network orchestration mechanisms in relation to the development of the value platform. The effects on activities of network members beyond this scope have not been explicitly drawn out but should not be underestimated. Network orchestration mechanisms can generate new metrics around the emergent value, enhanced innovativeness of network members and legitimization of their creative activities. Network partners can leverage such metrics to shift allegiances if inclined to do so. Demonstration of the way they develop complementary value can be appealing to competitors of the lead firm and can encourage network partners to move on to stronger roles in other networks.

\section{Managerial implications}

From a managerial standpoint, the findings from this study can assist practitioners in formulating and implementing a strategy for network-centric and value-centric platform leadership.

First, the findings suggest that lead firms should refrain from focusing chiefly on the platform's technical architecture and what has been done in the past. Also, as typical in many innovation projects, it is tempting for many firms to adopt an inside-in approach. This means firms focus on what is technically possible and known, fixating around existing routines and capabilities. Whilst investing in and supporting network partners is generally acknowledged as important by managers, enabling the network to craft and nurture value around their platform can be unnerving. The findings from this study delineate a number of practices, which support this process. Deploying such practices requires attention to both the selection of partners and the nurturing of organization-wide support.

Value platform development may require either making adjustments to existing relationships with network partners or establishing relationships with new network partners, or both. Investment in strong relational ties with key decision makers in new partnering organizations is critical. Pre-existing relationships with network partners can be both a blessing and a curse for platform value development. Partners may be reluctant to change existing behaviors and mindsets. The new platform may require a new business logic requiring radical change, which may be beyond existing established network partner's capabilities. New resources and competence development may be out of reach for some partners. Hence, rather than involving the entire network in the new platform, firms might carefully target key partners in specific markets, before scaling up the value platform. 
Second, the findings alert managers to the need to nurture organizational support for the emergent value platform from an early stage. Many of the adverse practices, unraveled from across our cases, relate to organizational inertia or resistance to change. Whilst this is a commonly known blockage to innovation, a network-centric platform approach makes change particularly onerous. Specifically, senior management needs to embrace a strategic intent to be network-centric in developing value platforms. The study findings suggest that managers need to allow and support network-led interpretations of what the platform entails. This means internally redefining how to make sense of innovation coming from the network by employing different metrics and parameters than is usual in innovation efforts. To do so, middle level managers should initiate internal workshops to disseminate and educate the wider and more senior members of the organization about the value platform. This should not only concern platform-specific performance indicators and success stories but also the network-integrating process itself. Managers should also invite network members to be part of such regular workshops, telling their own stories and spreading diverse perspectives on the process.

Third, our research shows that the network orchestration mechanisms cannot be considered in isolation. Managers should put in place ways to adopt a holistic view of value platform evolution. They should put attention to the inter-dependencies and network-wide consequences of the practices they adopt. Leveraging one set of practices may have adverse effect if another set of practices is not deployed. For example, having a network-inspired vision for the platform is unlikely to accrue benefits unless the firm develops metrics and indicators to show progress towards achieving that vision. Managers can evaluate their firms' strengths in each of the sets of practices underpinning the identified mechanisms. It is unlikely they have the skills to leverage across all areas. Understanding the interdependencies between the mechanisms can direct managers towards investing in required resources and capabilities as needed.

\section{Limitations and further research}

This research provides novel insight into how lead firms orchestrate value platform development in network settings. The study has certain limitations, some of which offer fruitful opportunities for further research. First, variety seeking motivated the case sampling. The cross-case comparison showed that, whilst practices differed these differences were 
marginal and did not affect the validity of the findings across the cases. However, further research could focus on identifying differences in orchestration mechanisms dependent on the characteristics of the value platform such as novelty and complexity. An additional extension of the research would be to validate the proposed orchestration mechanisms and their relationships in a cross-sectional study. This would involve developing measures for the identified practices underlying the mechanisms and test the proposed relationships.

Second, this study focuses on value platform development where the network is orchestrated by lead firms. It hence focuses on practices performed by lead firms. Whilst other network actors were interviewed, this was primarily to triangulate data rather than to uncover and detail their practices. This approach is commonly adopted in network research, but its limitations in forwarding a network perspective are heeded. While value appropriation is a key issue in platform management (Nambisan and Sawhney, 2011) and strategic network construction and operating (Dhanaraj and Parkhe 2006; Partanen and Möller, 2010), given the research design, this study has not focused on disentangling specifically how partners can appropriate value from the platform. Further research might explore this issue by also studying the practices of other network actors.

Finally, while studies of platform development privilege managed networks rather than emergent ones, additional research might assess initiated, influenced, and actively codeveloped value platforms by other actors beyond the traditional lead firm. Innovation research shows that many novel value propositions are the results of customer and other stakeholder input (Lilien et al., 2002). Adopting additional stakeholder perspectives would enrich the lead firm orientation adopted in this study.

\section{References}

Agranoff, R. and McGuire, M. (2001). Big questions in public network management research. Journal of Public Administration Research and Theory, 11(3), 295-326.

Anderson, J.C., Håkansson, H. and Johanson, J. (1994). Dyadic business relationships within a business network context. Journal of Marketing, 58(4), 1-15.

Armstrong, M. (2006). Competition in two-sided markets. The RAND Journal of Economics, $37(3), 668-691$.

Bitektine, A. and Haack, P. 2015. The "Macro" and the "Micro" of Legitimacy: Toward a Multilevel Theory of the Legitimacy Process. Academy of Management Review, 40(1), 49-75 
Cattani G and Ferriani S (2008). A core/periphery perspective of individual creative performance: Social networks and cinematic achievements in the Hollywood Film Industry, Organization Science, 29, 824-844.

Chakravarty, A., Kumar, A. and Grewal, R. (2014). Customer Orientation Structure for Internet-Based Business-to-Business Platform Firms. Journal of Marketing, 78(5), 1-23.

Coleman, J. S. (1958). Relational analysis: The study of social organizations with survey methods. Human Organization, 17, 28-36.

Cook, K.S. and Emerson, R.M. (1978). Power, equity and commitment in exchange networks. American sociological review, 721-739.

Corsaro, D., Ramos, C., Henneberg, S.C. and Naudé, P. (2012). The impact of network configurations on value constellations in business markets-The case of an innovation network. Industrial Marketing Management, 41(1), 54-67.

Cusumano, M.A. and Gawer, A. (2002). The elements of platform leadership. MIT Sloan Management Review, 43(3), 51-58.

Dacin, M.T., Oliver, C. and Roy, J.P. (2007). The legitimacy of strategic alliances: An institutional perspective. Strategic Management Journal, 28(2), 169-187.

Dagnino, G.B., G. Levanti and A. Mocciaro Li Destri, (2016), Structural dynamics and intentional governance in strategic interorganizational network evolution: A multilevel approach, Organization Studies, 37(3), 349-373.

Davis, G. F. and Marquis, C. (2005). Prospects for organization theory in the early twentyfirst century: institutional fields and mechanisms. Organization Science, 16(4), 332-343.

Dhanaraj, C. and Parkhe, A. (2006). Orchestrating innovation networks. Academy of Management Review, 31(3), 659-669.

Dowling, J. and Pfeffer. J. (1975). Organizational legitimacy: Social values and organizational behavior." Pacific Sociological Review, 18(1), 122-136.

Eisenhardt, K.M. (1989). Building theories from case study research. Academy of Management Review, 14(4), 532-550.

Eisenhardt, K.M. and Graebner, M.E. (2007). Theory building from cases: Opportunities and challenges. Academy of Management Journal, 50(1), 25-32.

Eloranta, V. and Turunen, T. (2016). Platforms in service-driven manufacturing: Leveraging complexity by connecting, sharing, and integrating. Industrial Marketing Management, 55, 178-186.

Evans, D.S. (2003). Some empirical aspects of multi-sided platform industries. Review of Network Economics, 2(3), 325-382.

Ford, D. (2011). IMP and service-dominant logic: Divergence, convergence and development. Industrial Marketing Management, 40(2), 231-239.

Gawer, A. (2009). Platform dynamics and strategies: from products to services, (Ed.) Gawer, A. Platforms, markets and innovation, Edgar Elgar, UK. 
Gawer, A. and Cusumano, M.A. (2014). Industry platforms and ecosystem innovation. Journal of Product Innovation Management, 31(3), 417-433.

Gemünden, H.G., Ritter, T. and Heydebreck, P. (1996). Network configuration and innovation success: An empirical analysis in German high-tech industries. International Journal of Research in Marketing, 13(5), 449-462.

Hansen M T, (2002). Knowledge networks: Explaining effective knowledge sharing in multi unit companies. Organization Science, 13, 615-635.

Håkansson, H. and A-K. Eriksson, (1993), Getting Innovations out of Buyer-Supplier Relationships, Journal of Business-to-Business Marketing, 1(2), 3-34.

Håkansson, H and D. Ford, (2002), How should companies interact in business networks?, Journal of Business Research, 55(2), 133-139.

Hernes, G. (1998). Real virtuality. (Eds.) P. Hedström, R. Swedberg. Social Mechanisms: An Analytical Approach to Social Theory. Cambridge University Press, New York, 74-101.

Hinterhuber, A. (2002). Value chain orchestration in action and the case of the global agrochemical industry. Long Range Planning, 35(6), 615-635.

Huang, G.Q., Zhang, X.Y. and Lo, V.H. (2007). Integrated configuration of platform products and supply chains for mass customization: a game-theoretic approach. IEEE Transactions on Engineering Management, 54(1), 156-171.

Human S and Provan K G (2000). Legitimacy building in the evolution of small-firm multilateral networks: A comparative study of success and demise. Administrative Science Quarterly, 45, 327-365.

Huxham, C. and Vangen, S. (2000). Leadership in the shaping and implementation of collaboration agendas: How things happen in a (not quite) joined-up world. Academy of Management Journal, 43(6), 1159-1175.

Jaakkola, E. and T. Hakanen (2013). Value co-creation in solution networks. Industrial Marketing Management, 42, 47-58.

Jansson, H., Johanson, M. and Ramström, J. (2007). Institutions and business networks: A comparative analysis of the Chinese, Russian, and West European markets. Industrial Marketing Management, 36(7), 955-967.

Jarillo, J.C. (1988). On strategic networks. Strategic management journal, 9(1), 31-41.

Jiang, B., Jerath, K. and Srinivasan, K. (2011). Firm strategies in the "mid tail" of platformbased retailing. Marketing Science, 30(5), 757-775.

Ketchen, D. J., Hult, T. G. M., \& Slater, S. F. (2007). Toward greater understanding of market orientation and the resource-based view. Strategic Management Journal, 28(9), 961964.

Kowalkowski, C., Gebauer, H. and Oliva, R. (2017). Service growth in product firms: Past, present, and future. Industrial Marketing Management, 60, 82-88. 
Kowalkowski, C., Kindström, D. and Carlborg, P. (2016). Triadic value propositions: when it takes more than two to tango. Service Science, 8(2), 282-299.

Kowalkowski, C., Witell, L. and Gustafsson, A. (2013). Any way goes: Identifying value constellations for service infusion in SMEs. Industrial Marketing Management, 42(1), 18-30.

Laari-Salmela, S., Mainela, T. and Puhakka, V. (2015). Beyond network pictures: Situational strategizing in network context. Industrial Marketing Management 45, 117-127.

Leonard-Barton, D. (1990). A dual methodology for case studies: Synergistic use of a longitudinal single site with replicated multiple sites. Organization Science, 1(3), 248-266.

Letaifa, S.B., Edvardsson, B. and Tronvoll, B. (2016). The role of social platforms in transforming service ecosystems. Journal of Business Research, 69(5), 1933-1938.

Lilien, G.L., Morrison, P.D., Searls, K., Sonnack, M. and von Hippel, E. (2002). Performance assessment of the lead user idea-generation process for new product development. Management Science, 48(8), 1042-1059.

Lipparini, A., Lorenzoni, G., and Ferriani, S. (2014). From core to periphery and back: A study on the deliberate shaping of knowledge flows in interfirm dyads and networks. Strategic Management Journal, 35, 578-595.

Lorenzoni, G. and Lipparini, A. (1999). The leveraging of interfirm relationships as a distinctive organizational capability: a longitudinal study. Strategic Management Journal, 20(4), 317-338.

Low, B. and Johnston, W.J. (2010). Organizational network legitimacy and its impact on knowledge networks: the case of China's TD-SCDMA mobility technology. Journal of Business \& Industrial Marketing, 25(6), 468-477.

Lusch, R.F. and Nambisan, S. (2015). Service Innovation: A Service-Dominant Logic Perspective. MIS Quarterly, 39(1), 155-175.

Lyons, R. K., J. A. Chatman, and C. K. Joyce. 2007. Innovation in services: Corporate culture and investment banking. California Management Review, 50(1), 174-191.

Macdonald, E. K., M. Kleinaltenkamp, and H. N. Wilson. 2016. How business customers judge solutions: solution quality and value in use. Journal of Marketing, 80 (2), 96-120.

Meyer, M.H. and Lehnerd, A.P. (1997). The power of product platforms. New York, NY, Simon \& Schuster.

Meyer, M.H. and Mugge, P.C. (2001). Make platform innovation drive enterprise growth. Research Technology Management, 44(1), 25-39.

Miles, M. B., and Huberman, A.M. (1984). Qualitative data analysis: A sourcebook of new methods. N.Y., Sage publications.

Möller, K.K. \& Halinen, A. (1999). Business relationships and networks: Managerial challenge of network era. Industrial Marketing Management, 28(5), 413-427.

Möller, K. and Rajala, A. (2007). Rise of strategic nets: New modes of value creation. Industrial Marketing Mangement, 36(7), 895-908. 
Möller, K. and Svahn, S. (2003). Managing strategic nets: a capability perspective. Marketing Theory, 3(2), 201-226.

Möller, K. and Svahn, S. (2006). Role of Knowledge in Value Creation in Business Nets. Journal of Management Studies, 43(5), 985-1007.

Möller, K. and Svahn, S. (2009). How to influence the birth of new business fields-Network perspective. Industrial Marketing Management, 38(4), 450-458.

Müller-Seitz, G. (2012). Leadership in interorganizational networks: a literature review and suggestions for future research. International Journal of Management Reviews, 14(4), 428443.

Muller-Seitz G. and Sydow J (2012). Maneuvering between networks to lead: A longitudinal case study in the semi-conductor industry. Long Range Planning, 45, 105-135.

Nambisan, S. and Sawhney, M. (2011). Orchestration processes in network-centric innovation: Evidence from the field. Academy of Management Perspectives, 25(3), 40-57.

Normann, R. and Ramírez, R. (1993). From value chain to value constellation: Designing interactive strategy. Harvard Business Review, 71(4), 65-77.

Palo, T. and Tähtinen, J. (2011). A network perspective on business models for emerging technology-based services. Journal of Business \& Industrial Marketing, 26(5), 377-388.

Paquin, R.L. and Howard-Grenville, J. (2013). Blind dates and arranged marriages:

Longitudinal processes of network orchestration. Organization Studies, 34(11), 1623-1653.

Parolini, C. (1999). The Value Net: A tool for Competitive Advantage. Chichester, UK, Wiley.

Partanen, J. and K. Möller (2012). How to build a strategic network: A practitioner-oriented process model for the ICT sector. Industrial Marketing Management, 41, 481-494.

Piekkari, R., Plakoyiannaki, E. and Welch, C. (2010). 'Good'case research in industrial marketing: Insights from research practice. Industrial Marketing Management, 39(1), 109117.

Provan, K. G. and Kenis, P. (2008). Modes of network governance: Structure, management, and effectiveness. Journal of Public Administration Research and Theory, 18(2): 229-252.

Raddats, C., Zolkiewski, J., Story, V., Burton, J., Baines, T. and Bigdeli, A. Z. (2017). Interactively developed capabilities: Evidence from dyadic servitization relationships. International Journal of Operations and Production Management, 37(3), 382-400.

Reckwitz, A. (2002). Toward a theory of social practices: A development in culturalist theorizing. European Journal of Social Theory, 5(2), 243-263.

Ritter, T., Wilkinson, I.F. and Johnston, W.J. (2004). Managing in complex business networks. Industrial Marketing Mangement, 33(3), 175-183.

Ritvala, T., and Salmi, A. (2010). Value-based network mobilization: A case study of modern environmental networkers. Industrial Marketing Management, 39(6), 898-907. 
Sawhney, M., Verona, G. and Prandelli, E. (2005). Collaborating to create: The Internet as a platform for customer engagement in product innovation. Journal of Interactive Marketing, 19(4), 4-17.

Sawhney, M.S. (1998). Leveraged high-variety strategies: from portfolio thinking to platform thinking. Journal of the Academy of Marketing Science, 26(1), 54-61.

Simpson, T.W., Siddique, Z. and Jiao, J. (2005). Platform-based Product Development: Introduction and Overview. Product Platform and Product Family Design: Methods and Applications. T. W. Simpson, Z. Siddique \& J. Jiao. New York, NY, Springer, 1-15.

Sköld, M. and Karlsson, C. (2007). Multibranded platform development: a corporate strategy with multimanagerial challenges. Journal of Product Innovation Management, 24(6), 554566.

Sridhar, S., Mantrala, M.K., Naik, P.A. and Thorson, E. (2011). Dynamic marketing budgeting for platform firms: Theory, evidence, and application. Journal of Marketing Research, 48(6), 929-943.

Stabell, C.B. and Fjeldstad, O.D. (1998). Configuring value for competitive advantage: On chains, shops, and networks. Strategic Management Journal, 19(5), 413-437.

Suchman, M.C. (1995). Managing legitimacy: Strategic and institutional approaches. Academy of management review, 20(3), 571-610.

Thomas, L., E. Autio and D.M. Gann, (2014), Architectural leverage: putting platforms in context, Academy of Management Perspectives, 28(2), 198-219.

Vargo, S.L. and Lusch, R.F. (2008). Service-dominant logic: continuing the evolution. Journal of the Academy of Marketing Science, 36(1), 1-10.

Vargo, S.L., Heiko Wieland, and Melissa Archpru Akaka. (2015) Innovation through institutionalization: A service ecosystems perspective. Industrial Marketing Management, 44, 63-72.

van Riel, A. C. R., Calabretta, G., Driessen, P. H., Hillebrand, B., Humphreys, A., Krafft, M., \& Beckers, S. F. M. (2013). Consumer perceptions of service constellations: implications for service innovation. Journal of Service Management, 24(3), 314-329.

Wernerfelt, B. (1984). A resource-based view of the firm. Strategic Management Journal, $5(2), 171-180$.

Windahl, C. and Lakemond, N. (2006). Developing integrated solutions: The importance of relationships within the network. Industrial Marketing Management, 35(7), 806-818.

Yin, R. K. (2014) Case study research: Design and methods. New Delhi, India: Sage Publications.

Zimmerman, M.A. and Zeitz, G.J. (2002). Beyond survival: Achieving new venture growth by building legitimacy. Academy of Management Review, 27(3), 414-431. 
Table 1: Studies of network and platform management practices.

\begin{tabular}{ll}
\hline Study & \multicolumn{1}{c}{ Practices } \\
\hline $\begin{array}{l}\text { Management } \\
\text { functions in }\end{array}$ & $\begin{array}{l}\text { 1. Framing: establishing and influencing the operating rules of the network and altering the } \\
\text { perceptions of the network members. }\end{array}$ \\
networks & 2. Activating: identifying participants for and structuring the network. \\
(Agranoff and & 3. Mobilizing: building commitment among actors. \\
McGuire, 2001; & 4. Synthesizing: organizing and controlling, including creating conditions for interaction \\
Järvensivu and & while minimizing obstacles to cooperation.
\end{tabular}

Möller, 2009)

Network mobilization model (Mouzas and Naudé, 2007)

1. Developing network insight: a firm's unique knowledge about the niche it occupies in the network.

2. Introducing new business propositions: propose to customers or suppliers' cooperative projects for implementation or intents for inter-organizational exchange.

3. Concluding the deal: create joint gains and mobilize other actors to work within the firm's plans.

4. Developing the social contract: clarify the expectation regarding the nature, extent, and length of a jointly decided action.

Phases of new 5. Achieving sustained mobilization: ensure genuine concurrence of others.

business

1. Exploration for future business opportunities: local innovation and widespread ideas related to emerging science and technologies, involving flux and uncertainty.

emergence

(Möller and

Svahn, 2009)

2. Mobilization for application: competition to develop winning applications, which may end up becoming dominant designs.

3. Coordination for dissemination: competition to achieve rapid growth through strong channel coverage and efficient production, marketing, and logistics.

Strategic network building process (Partanen and

1. Determine the value-creation activities for the end customer: focus is on the final customers' needs, desires or problems that the firm hopes to address, and on the valuecreation activities that these imply

Möller, 2012)

2. Determine the value-creating system: create a view of the business concept underlying the targeted customer value creation and envisioned offering.

3: Determine the core company objectives and analyze the target activities: determine which activities it wants to carry out internally and which to leave for the network partners.

4. Compare resources and capabilities with the target activities: link value activities with the resource pool of the lead firm.

5. Analyze the delegated activities: providing the lead firm with a clear understanding of the business environment of its partners.

6. Conduct preliminary partner assessment: mapping and assessing potential partners for the delegated value activities.

7. Negotiate with partner candidates: develop a more in-depth picture of partner candidates.

8. Launch inter-firm collaboration: develop and nurture inter-organizational trust.

Common network orchestration actions (Dagnino et al., 2014)

1. Attract and mobilize organizations towards the network through legitimacy-building activities.

2. Shaping the conditions under which the network operates, thereby "making things happen."

3. Enhance knowledge and resource mobility, manage value appropriation, and enable network growth.

4. Generate and share knowledge by means of purposefully implemented knowledgeenhancing practices between organizations.

Hub firm's orchestration processes

(Nambisan and

Sawhney, 2011)

Effective practices for platform leadership (Gawer and Cusumano, 1a. Managing innovation coherence: redefine the platform to meet new market requirements, rally partners to adapt their complementary offerings, and coordinate knowledge sharing. 1b. Managing innovation appropriability: establish and operate an open modus operandi that enables partners to appropriate value.

2. Managing innovation leverage: establish a joint repository for partners to share their proprietary assets with one another.

1. Develop a vision of how a product, technology, or service could become an essential part of a larger business ecosystem: identify complementor firms and an element with platform potential.

2. Build the right technical architecture and "connectors": adopt a modular technical architecture and share intellectual property. 
3. Build a coalition around the platform: share the vision and rally complementors into cocreating a vibrant ecosystem together.

4. Evolve the platform while maintaining a central position and improving the ecosystem's vibrancy: keep innovating on the core and make long-term investments in coordination activities. 


\section{Table 2: Overview of the value platforms}

Insure is a value platform based on a vehicle telematics-based insurance service. This study focuses on its early stage launch on to the UK market and incremental development. The lead firm is Insurance Co which is a UK-based start-up company which grew to 180 employees by 2015 and saw, early on in the development process, the value of the platform for external actors.

The development process shows a radical departure from the producer-centric approaches to service innovation prevalent in the sector. Insurance Co was experimenting with a new co-creation model of developing a new service, engaging intensively with a network of partners that could enable a unique constellation based on new telematics technology, connectivity and knowledge.

CareHealth is a value platform based on a training academy for the lead firm customers. The project was initiated around insight that customers had problems finding the time to develop the competence of their employees. The lead firm, Healthcare Co, is an international company with headquarters in the UK. It specializes in the design, manufacture and supply of human waste management. It has 200 employees that serve 50 overseas markets.

Whilst the company had traditionally been product-centric it started developing new services and product/service bundles, such as training, audits and engineering support. The value platform was developed and refined over a period of four years in collaboration with a network of partners that could provide a resource constellation of knowledge, contacts and service personnel.

Telenav is a value platform developed around system and services for better dealer processes and customer machine operations. The first version of the value platform was launched in 2009 and has since been continuously reconfigured. The numbers of network members and connected machines have grown rapidly, although commercial success has not followed.

The lead firm, Infrastructure Co, is a multinational company incumbent in the construction industry. Most platform-enabled services are given away for free to their customers by the value platform actors. The value platform was initially seen as one of several systems offered to dealers to help them understand their customers. Based on a resource constellation including a IT-solution and connected machines together with knowledge about dealer and customer behavior, the platform could enable novel services to customers.

FleetServices addresses safer and more productive operations of customers. The first ideas of the value platform originated in 2007, although the first beta version was not launched until 2014.

FleetofTrucks Co (lead firm) is a multinational manufacturer of industrial turf equipment. Over five years, much effort was spent on understanding the needs of its customers and dealers, and reconfiguring and refining the value platform. The platform is new to the industry and required a radically different approach to service, so the lead firm had to convince the network actors of its potential value. A key resource in this work was customers and new work practices.

Bedcare is based on environmentally friendly laminate products and is intended to reduce the risks of cross infection in healthcare. It views the hospital bed as a value platform for service provision. A beta version of the value platform was tested at a customer, but so far, the value platform has not been a commercial success.

The lead firm, Hospital Solutions Co, has 40 employees and is a producer of laminate products to a range of industries. The value platform was developed and refined over a period of two years in collaboration with a network of partners. The network configuration of resources includes laminate products, burners, knowledge about work practices and cross infections and related costs.

CoffeePro is a coffee solution for the B2B market. The value platform is built around creating seamless solutions, in conjunction with network actors, for customers. It focuses on teaching customers about coffee, and building the brand. To meet intense competition, the value platform evolved and has been refined over time.

The lead firm, Coffee Co, a family owned business founded in 1906, is one of the biggest coffee roasters in the Nordic region. The network configuration of resources includes a logistic solution, a web platform, together with a high-quality product and knowledge about coffee. 
Table 3: Details of the cases

\begin{tabular}{|c|c|c|c|c|c|}
\hline $\begin{array}{l}\text { Value } \\
\text { platform }\end{array}$ & $\begin{array}{l}\text { Description of the } \\
\text { value platform }\end{array}$ & $\begin{array}{l}\text { Time period of } \\
\text { platform development }\end{array}$ & $\begin{array}{l}\text { Lead firm } \\
\text { (No. employees) }\end{array}$ & Additional value platform actors & $\begin{array}{l}\text { Interviews } \\
\text { (Actors and timing) }\end{array}$ \\
\hline Insure & $\begin{array}{l}\text { A new car insurance } \\
\text { concept }\end{array}$ & January 2011 - ongoing & $\begin{array}{c}\text { Insurance Co } \\
(180)\end{array}$ & $\begin{array}{l}\text { Installation company, suppliers of } \\
\text { hardware, website design, } \\
\text { distributors, intermediaries, end-users }\end{array}$ & $\begin{array}{l}33 \text { (22 in lead firm; } 11 \text { in } \\
\text { network actors) } \\
\text { First interview: July } 2011 \\
\text { Last interview: June } 2014\end{array}$ \\
\hline CareHealth & $\begin{array}{l}\text { Care for Health } \\
\text { training academy }\end{array}$ & June 2012 - June 2016 & $\begin{array}{l}\text { Healthcare Co } \\
\text { (200) }\end{array}$ & $\begin{array}{l}\text { Suppliers, The National health } \\
\text { Service, Foundations Trusts, } \\
\text { hospitals, universities, distributors, a } \\
\text { consultancy company, translation and } \\
\text { marketing agency, online research } \\
\text { agency }\end{array}$ & $\begin{array}{l}7 \text { ( } 4 \text { in lead firm; } 3 \text { in network } \\
\text { actors) } \\
\text { First interview: July } 2013 \\
\text { Last interview: September } 2014\end{array}$ \\
\hline Telenav & $\begin{array}{l}\text { A system for better } \\
\text { dealer processes and } \\
\text { customer machine } \\
\text { operations }\end{array}$ & $\begin{array}{l}\text { January } 2009 \text { - } \\
\text { ongoing }\end{array}$ & $\begin{array}{l}\text { Infrastructure Co } \\
\qquad(15000)\end{array}$ & Regional and local units & $\begin{array}{l}17 \text { (11 lead firm; } 6 \text { network } \\
\text { actors) } \\
\text { First interview: June } 2010 \\
\text { Last interview: February } 2015\end{array}$ \\
\hline FleetServices & $\begin{array}{l}\text { A system for safer and } \\
\text { more productive } \\
\text { customer operations }\end{array}$ & $\begin{array}{l}\text { September } 2007 \text { (beta } \\
\text { mode since August } \\
\text { 2014)- ongoing }\end{array}$ & $\begin{array}{l}\text { FleetofTrucks Co } \\
\qquad(14000)\end{array}$ & Dealers and customers & $\begin{array}{l}49 \text { (11 lead firm; } 38 \text { network } \\
\text { actors) } \\
\text { First interview: June } 2007 \\
\text { Last interview: January } 2014\end{array}$ \\
\hline Bedcare & A hospital bed system & $\begin{array}{l}\text { September } 2014 \text { - } \\
\text { ongoing }\end{array}$ & $\begin{array}{l}\text { Hospital Solutions } \\
\text { Co (40) }\end{array}$ & $\begin{array}{l}\text { Architect, a product-design company, } \\
\text { a pilot customer, and a service } \\
\text { provider. }\end{array}$ & $\begin{array}{l}10 \text { ( } 8 \text { lead firm; } 1 \text { network actor) } \\
\text { First interview: January } 2015 \\
\text { Last interview: September } 2016\end{array}$ \\
\hline CoffeePro & $\begin{array}{l}\text { A coffee solution for } \\
\text { the } B 2 B \text { market. }\end{array}$ & $\begin{array}{l}\text { January } 2014- \\
\text { ongoing }\end{array}$ & Coffee Co (150) & $\begin{array}{l}\text { Suppliers of equipment, suppliers of } \\
\text { consumables, sub-contractors of } \\
\text { maintenance, and customers }\end{array}$ & $\begin{array}{l}9 \text { ( } 8 \text { lead firms, } 1 \text { network actor }) \\
\text { First interview: January } 2014 \\
\text { Last interview: May } 2016\end{array}$ \\
\hline
\end{tabular}


Table 4: Indicative evidence of network orchestration practices for value platform development

\begin{tabular}{|c|c|c|}
\hline $\begin{array}{c}\text { Orchestration } \\
\text { mechanism }\end{array}$ & Practice & Empirical illustration \\
\hline \multirow[t]{5}{*}{ Envisioning } & $\begin{array}{l}\text { Envisioning } \\
\text { complementary value } \\
\text { from network }\end{array}$ & $\begin{array}{l}\text { At CoffeePro, the lead firm relied on their network to add } \\
\text { complementary value. For instance, one of the network actors developed } \\
\text { an application to keep track on all coffee machines. This app keeps track } \\
\text { on the machine's performance and when it needs maintenance and } \\
\text { replacement. The app adds value, in terms of customer knowledge, to } \\
\text { the whole network as the lead firm does not profit from the machines. }\end{array}$ \\
\hline & $\begin{array}{l}\text { Crafting of network } \\
\text { roles to enhance the } \\
\text { platform }\end{array}$ & $\begin{array}{l}\text { In the Insure case, the lead firm anticipated an additional search role of } \\
\text { a new technology partner, beyond specified technology development } \\
\text { tasks. The network member took on this extra intermediary } \\
\text { responsibility to find and secure a new installation company for the } \\
\text { telematics box and further helped develop the new company's role and } \\
\text { needed tasks/responsibilities. }\end{array}$ \\
\hline & $\begin{array}{l}\text { Identifying value } \\
\text { misalignments within } \\
\text { the network }\end{array}$ & $\begin{array}{l}\text { The dealer/customer workshops organized by FleetServices lead firm } \\
\text { enabled it to identify value misalignments. The analyses of the network } \\
\text { actors provided a better understanding of what would be required from } \\
\text { each actor in order to advance the platform. For example, the lead firm } \\
\text { anticipated early on that the dealers would have to change their norms, } \\
\text { rules, and activities from reactive repair to proactive maintenance. }\end{array}$ \\
\hline & $\begin{array}{l}\text { Product or technical } \\
\text { focus of platform } \\
\text { communicated to the } \\
\text { network }\end{array}$ & $\begin{array}{l}\text { The lead firm in Telenav struggled to charge for the new services since } \\
\text { it (initially) were unable to define the value potential in monetary terms. } \\
\text { While the technical features proved easier to communicate to service } \\
\text { partners and customers, charging for the services required a thorough } \\
\text { understanding of the operations of each specific customer. }\end{array}$ \\
\hline & $\begin{array}{l}\text { Adherence to pre- } \\
\text { existing roles of } \\
\text { network members }\end{array}$ & $\begin{array}{l}\text { The lead firm at CoffeePro continued an inappropriate price-based } \\
\text { relationship with a key actor in its network, failing to develop its role } \\
\text { towards enhancing quality and sustainability. As a consequence, the key } \\
\text { actor tried to price CoffePro product differently in order to make the } \\
\text { customer select competitive brands. }\end{array}$ \\
\hline \multirow[t]{3}{*}{$\begin{array}{l}\text { Inducing } \\
\text { innovativeness }\end{array}$} & $\begin{array}{l}\text { Freely revealing } \\
\text { platform knowledge }\end{array}$ & $\begin{array}{l}\text { In the Insure case, the lead firm disseminates the way it utilizes } \\
\text { telematics data in its platform development throughout US and Europe } \\
\text { (through media and presentations). This generates wider awareness of } \\
\text { telematics technology which supports their technology partner's } \\
\text { business }\end{array}$ \\
\hline & $\begin{array}{l}\text { Investing in processes to } \\
\text { support network } \\
\text { innovation advances } \\
\text { around the platform }\end{array}$ & $\begin{array}{l}\text { In the CareHealth case study close support from the lead firm induced a } \\
\text { consultant network partner to develop a novel platform piloting process } \\
\text { customized to the lead firm. It then deployed its own resources further } \\
\text { by utilizing its own team of trainers for focus groups around the new } \\
\text { platform in targeted overseas markets. }\end{array}$ \\
\hline & $\begin{array}{l}\text { Retention of platform } \\
\text { knowledge }\end{array}$ & $\begin{array}{l}\text { The lead firm in the Bedcare case was reluctant to share the platform } \\
\text { vision, so its network partners found alternative ways to provide value to } \\
\text { customers. They bypassed the value platform by using a cheaper } \\
\text { solution or through capturing the value through a competitive platform. }\end{array}$ \\
\hline
\end{tabular}


Firm-centric assessment

of capabilities and resources of network members

Legitimizing

\section{Adjusting with network}

Developing and communicating metrics around emergent value

Demonstrating platform value to others beyond the network

Generation of inappropriate value platform metrics

Seeking advice from network on potential organizational adjustments

Verifying intended organizational adjustments with network members

Fixing resources and routines around original value
In both the FleetServices and Telenav cases, on a regional and local level, the lead firms had extensive knowledge about their dealer networks. The knowledge was however rather limited to the traditional product businesses (sales, spare parts, etc.), which hampered management when they were about to induce platform-enabled innovativeness into their networks.

The lead firm in CoffeePro shows the value they deliver to their customers by putting a price on education and demonstrates to the network the value/cost of customer maintenance. "CoffeePro knows more about the customers' inventory than the customers do", suggested a network partner who was beginning to understand their role in enhancing the platform.

The lead firms in the FleetServices and Telenav cases used their global and national social media channels to promote their value platforms. This enabled them to visualize and make more tangible novel service concepts on customer markets that managers in both firms refer to as "conservative." They were also able to reach a broader audience, including potential influencers.

At CareHealth, although metrics were in place to legitimize the network-centric value platform to external bodies, these were not adapted for internal stakeholders, leading to delays in approving budgets and internal resource access conflicts.

Structural changes took place at Telenav, evidenced by on-going investments in new service units. These were developed in conjunction with central and regional platform specialists to support its local sales companies and dealers.

The lead firm in CoffeePro built up customer competences around the product and around handling of their product. Core to these shifts were practices to involve the network.

The lead firm in FleetServices lacked experience of, and had rather few resources for, a shift towards value platform development. The platform innovation was unlike anything it had done in the past. Through collaboration with an academic partner, it was able to gain valuable insights to justify to its own senior management the need to direct investments differently: "Our academic collaboration has created a useful forum in which a small team has been able to see and benchmark [with other companies] and to verify that we are doing things right. For the few of us working with this it has been very valuable" (Director of Services).

The lead firm at CareHealth struggled to make necessary internal selfadjustments. Senior Board level management was slow in approving budgets for network-centric activities. Its thinking and decision-making was firmly fixed around traditional product and service parameters. 
Table 5: Lead firm orchestration mechanisms and practices for value platform development in a network setting across the cases

\begin{tabular}{|c|c|c|c|c|c|c|}
\hline $\begin{array}{l}\text { Orchestration mechanisms } \\
\text { and practices }\end{array}$ & Insure & $\begin{array}{l}\text { Care- } \\
\text { Health }\end{array}$ & Telenav & $\begin{array}{c}\text { Fleet } \\
\text { Services }\end{array}$ & Bedcare & CoffeePro \\
\hline $\begin{array}{l}\text { Envisioning } \\
\text { Envisioning complementary } \\
\text { value from network }\end{array}$ & $\begin{array}{c}\text { Extensive } \\
\mathrm{x}\end{array}$ & Low & Low & $\begin{array}{c}\text { Extensive } \\
\mathrm{x}\end{array}$ & Low & Low \\
\hline $\begin{array}{l}\text { Crafting of network roles to } \\
\text { enhance the platform }\end{array}$ & $\mathrm{x}$ & $\mathrm{x}$ & & $\mathrm{x}$ & & \\
\hline $\begin{array}{l}\text { Identifying value } \\
\text { misalignments within the } \\
\text { network }\end{array}$ & $\mathrm{x}$ & & & $\mathrm{x}$ & & $\mathrm{x}$ \\
\hline $\begin{array}{l}\text { *Product or technical focus } \\
\text { of platform communicated } \\
\text { to the network }\end{array}$ & & & $\mathrm{x}$ & & & $\mathrm{x}$ \\
\hline $\begin{array}{l}\text { *Adherence to pre-existing } \\
\text { roles of network members }\end{array}$ & & & $\mathrm{x}$ & & $\mathrm{X}$ & $\mathrm{X}$ \\
\hline $\begin{array}{l}\text { Inducing innovativeness } \\
\text { Freely revealing platform } \\
\text { knowledge }\end{array}$ & $\begin{array}{c}\text { Extensive } \\
\quad \mathrm{x}\end{array}$ & $\begin{array}{l}\text { Extensive } \\
\quad \mathrm{x}\end{array}$ & $\begin{array}{c}\text { Low } \\
x\end{array}$ & $\begin{array}{l}\text { Extensive } \\
\quad \mathrm{x}\end{array}$ & Low & Fair \\
\hline $\begin{array}{l}\text { Investing in processes to } \\
\text { support network innovation } \\
\text { advances around the } \\
\text { platform }\end{array}$ & $\mathrm{x}$ & $\mathrm{x}$ & & $\mathrm{x}$ & & $\mathrm{x}$ \\
\hline $\begin{array}{l}\text { *Retention of platform } \\
\text { knowledge }\end{array}$ & & & & $\mathrm{x}$ & $\mathrm{X}$ & \\
\hline $\begin{array}{l}\text { *Firm-centric assessment of } \\
\text { capabilities and resources } \\
\text { of network members }\end{array}$ & & & $\mathrm{x}$ & & $\mathrm{x}$ & \\
\hline Legitimizing & Low & Extensive & Fair & Low & Extensive & Extensive \\
\hline $\begin{array}{l}\text { Developing and } \\
\text { communicating metrics } \\
\text { around emergent value }\end{array}$ & & $x$ & & & $\mathrm{x}$ & $x$ \\
\hline $\begin{array}{l}\text { Demonstrating platform } \\
\text { value to others beyond the } \\
\text { network }\end{array}$ & $\mathrm{x}$ & $\mathrm{x}$ & & $\mathrm{x}$ & $\mathrm{x}$ & \\
\hline $\begin{array}{l}\text { *Generation of } \\
\text { inappropriate value } \\
\text { platform metrics }\end{array}$ & & & $\mathrm{x}$ & $\mathrm{x}$ & & $\mathrm{x}$ \\
\hline $\begin{array}{l}\text { Adjusting with network } \\
\text { Seeking advice from } \\
\text { network on potential } \\
\text { organizational adjustments }\end{array}$ & Low & Low & Low & $\begin{array}{c}\text { Low } \\
x\end{array}$ & $\begin{array}{c}\text { Fair } \\
\mathrm{X}\end{array}$ & $\begin{array}{c}\text { Low } \\
\mathrm{x}\end{array}$ \\
\hline $\begin{array}{l}\text { Verifying intended } \\
\text { organizational adjustments } \\
\text { with network members }\end{array}$ & & & & $\mathrm{x}$ & & \\
\hline $\begin{array}{l}\text { *Fixing resources and } \\
\text { routines around original } \\
\text { value }\end{array}$ & & & $\mathrm{x}$ & $\mathrm{x}$ & & \\
\hline
\end{tabular}

Note: practices indicated with $*$ and in italic are impeding practices. Other practices are facilitating practices. 


\section{Appendix}

Details of interviews with network actors within each case

\begin{tabular}{|c|c|c|c|}
\hline Case & Network Actor & Respondents & Interviews \\
\hline \multirow[t]{10}{*}{ Insure } & Lead firm & $\mathrm{CEO}$ & 5 \\
\hline & & Director & 4 \\
\hline & & Marketing manager & 3 \\
\hline & & Business development manager & 3 \\
\hline & & Designer & 3 \\
\hline & & $\begin{array}{l}\text { Website controller, Call center manager and } \\
\text { Call center employees } 1-2\end{array}$ & 4 \\
\hline & Installation Company & CEO, employees & 4 \\
\hline & Supplier (1) & $\mathrm{CEO}$, employees & 2 \\
\hline & Supplier (2) & CEO, employees & 1 \\
\hline & Customers & Customer A, B and C & 3 \\
\hline \multirow[t]{4}{*}{ CareHealth } & Lead firm & $\begin{array}{l}\text { Market research manager, marketing } \\
\text { manager, product specialist and business } \\
\text { development manager }\end{array}$ & 4 \\
\hline & Customer & Safety manager, Idea manager & 2 \\
\hline & Consultancy & $\mathrm{CEO}$ & 1 \\
\hline & Distributor & Operations manager & 1 \\
\hline \multirow[t]{4}{*}{ Telenav } & Lead firm & Global product manager & 3 \\
\hline & & $\begin{array}{l}\text { Global manager, Global telematics } \\
\text { manager, Product manager, Aftermarket } \\
\text { manager, Contract manager, Systems } \\
\text { manager, New business manager, } \\
\text { Professional services specialist, }\end{array}$ & 9 \\
\hline & Region units & Service director, product manager $1-2$ & 3 \\
\hline & Local units & $\begin{array}{l}\text { Project manager, Customer solution } \\
\text { manager }\end{array}$ & 2 \\
\hline \multirow[t]{4}{*}{ FleetServices } & Lead firm & Service manager & 6 \\
\hline & & $\begin{array}{l}\text { Marketing manager, Innovation manager, } \\
\text { Global sales manager, Regional sales } \\
\text { manager A and B }\end{array}$ & 5 \\
\hline & Commercial Dealers & $\begin{array}{l}\text { Managing director, Sales manager, Service } \\
\text { technician ( } 10 \text { dealers) }\end{array}$ & 11 \\
\hline & Customers & $\begin{array}{l}\text { Managing director, Service technician, } \\
\text { Operator ( } 22 \text { customers })\end{array}$ & 27 \\
\hline \multirow[t]{3}{*}{ Bedcare } & Lead firm & CEO & 4 \\
\hline & & Marketing manager & 6 \\
\hline & Customer & Manager & 1 \\
\hline \multirow[t]{3}{*}{ CoffePro } & Lead firm & $\mathrm{CEO}$ & 4 \\
\hline & & Marketing manager & 4 \\
\hline & Customer & Board member & 1 \\
\hline
\end{tabular}

